\title{
PERWUJUDAN GOOD GOVERNANCE MELALUI FORMAT REFORMASI BIROKRASI PUBLIK DALAM PERSPEKTIF HUKUM ADMINISTRASI NEGARA
}

Oleh:

Tedi Sudrajat

Fakultas Hukum Universitas Jenderal Soedirman Purwokerto

\begin{abstract}
Law Administration is being developing in atmosphere that governmental start to arrange the society in law aspect. It is impact with governmental orientation that to create development in society. Then generate implication in the form of usage a set component, element, or element of subsystem with all his attribute, where which one another and each other interconnected, and interdependent so that in its entirety is a[n integrated unity or a[n totality, and also have specificpurpose or role among the law system and state administrate system. In this article will be explained about a set component, element, or element of subsystem to influence Law Administration State by good governance in materialization of public bureaucracy reform in Indonesia.
\end{abstract}

Kata Kunci : Hukum Administrasi Negara, good governance dan reformasi birokrasi publik

\section{A. Pendahuluan}

Charles A. Beard, seorang historikus politik yang terkenal dengan bukunya berjudul Administration pada tahun 1937 berkata bahwa tidak ada satu hal untuk abad modern sekarang ini yang lebih penting dari administrasi. Kelangsungan hidup pemerintahan yang beradab dan kecenderungan kelangsungan hidup dari peradaban itu sendiri akan sangat tergantung atas kemampuan kita untuk membina dan mengembangkan suatu filsafat administrasi yang mampu memecahkan masalah-masalah masyarakat modern. ${ }^{1}$ Selain itu, James Burham seorang sarjana Amerika lainnya pernah pula mengatakan bahwa revolusi politik dan sosial akan timbul dan diselesaikan, akan tetapi akan ada revolusi pada abad modern ini yang tidak akan menimbulkan suatu kelas terpenting dalam suatu masyarakat yaitu managerial class. $^{2}$ Analisa tersebut menimbulkan suatu kesimpulan bahwa tegak rubuhnya suatu negara, maju mundurnya peradaban manusia serta timbul tenggelamnya bangsabangsa di dunia akan tergantung pada baik buruknya administrasi yang dimiliki. Faktor di atas memperlihatkan bahwa pembinaan dan pengembangan administrasi akan menciptakan perubahan dan kemajuan bangsa dengan pondasi

\footnotetext{
Sondang P. Siagian, 1996, Filsafat Administrasi, Jakarta: PT. Gunung Agung, hlm. 1

2 Ibid
}

faktor lingkungan (eco-logical factor) pada masing-masing karakter bangsanya.

Berkaitan dengan fungsi administrasi pemerintahan, maka upaya mewujudkan sistem pemerintahan yang demokratis, bersih dan berwibawa menjadi prioritas utama bagi rakyat dan pemerintahan Indonesia pada era reformasi dewasa ini. Reformasi birokrasi dalam bentuk pelayan-an publik sebagai salah satu tuntutan reformasi telah menjadi awal timbulnya kesadaran akan mekanisme pelayanan publik dan menjadi tonggak kesadaran pemerintah untuk menata sistem pemerintahannya. Semangat reformasi yang mewarnai pendayagunaan aparatur negara diarahkan untuk mewujudkan administrasi negara yang mampu mendukung kelancaran dan keterpaduan pelaksanaan tugas dan fungsi penyelenggaraan pemerintahan negara dan pembangunan guna menghadapi tantangan globalisasi. Upaya untuk mewujudkannya adalah dengan mempraktikkan prinsip-prinsip good governance (tata pemerintahan yang baik). ${ }^{3}$

Sekurang-kurangnya terdapat tiga alasan yang melatarbelakangi pemikiran bahwa birokrasi publik dapat mendorong pengem-

\footnotetext{
3 Bappenas, 2002, Tingkat Pemahaman Aparatur Pemerintah Terhadap Prinsip-Prinsip Tata Pemerintahan Yang Baik, Jakarta: Badan Perencanaan Pembangunan Nasional, hlm. 2.
} 
bangan praktik good governance, meliputi:

1. Perbaikan kinerja pelayanan publik dinilai penting oleh semua stakeholder, yaitu pemerintah, warga pengguna dan para pelaku pasar. Dalam hal ini pemerintah berkepentingan dengan legitimasi, karena semakin membaiknya pelayanan, maka akan memperkecil biaya birokrasi yang pada gilirannya dapat memperbaiki kesejahteraan warga pengguna dan efisiensi mekanisme pasar;

2. Pelayanan publik adalah ranah dari ketiga unsur governance dalam melakukan interaksi yang sangat intensif. Melalui penyelenggaraan layanan publik, pemerintah, warga sipil dan para pelaku pasar berinteraksi secara intensif sehingga apabila pemerintah dapat memperbaiki kualitas pelayanan publik, maka manfaatnya dapat dirasakan langsung oleh masyarakat dan pelaku pasar. Hal ini penting dilakukan agar stakeholder semakin percaya bahwa pemerintah telah serius melakukan perubahan. Adanya kepercayaan (trust) merupakan prasyarat yang sangat penting untuk mendukung praktik good governance;

3. Nilai-nilai yang selama ini mencirikan praktik good governance dapat diterjemahkan secara sederhana melalui pelayanan publik. Para pelaksana kegiatan dapat mengembangkan sistem pelayanan publik yang efisien dan berkeadilan, transparan, akuntabel serta partisipatif dan keberhasilan melaksanakan kegiatan tersebut akan menularkan ke ranah yang lain sehingga good governance secara bertahap dapat dilembagakan di dalam setiap kegiatan pemerintahan. ${ }^{4}$

Ketiga alasan tersebut mengindikasikan bahwa birokrasi dalam bentuk pelayanan publik akan mengarah pada pembentukan "good governance" dan hal ini akan dapat menjadi kenyataan dan berjalan dengan baik dengan adanya komitmen dan keterlibatan semua pihak yaitu pemerintah dan masyarakat. Karenanya, good governance yang efektif memer-lukan adanya alignment (koordinasi) yang baik dan integritas, profesional serta etos kerja dan moral yang

\footnotetext{
4 Agus Dwiyanto, 2008, Mewujudkan Good Governance Melalui Pelayanan Publik, Yogyakarta: Gadjah Mada University Press, hlm. 4-5.
}

tinggi. ${ }^{5}$ Hal tersebut memberikan makna bahwa sektor administrasi negara selalu berkaitan dengan pembinaan sumber daya manusia dalam pemerintahan dan karenanya akan timbul perubahan paradigma dalam pelayanan publik yang secara otomatis menciptakan perubahan dan penyesuaianpenyesuaian dalam pelaksanaan tugas, fungsi dan kewajibannya. Pola pikir pengembangan sumber daya manusia tersebut memiliki arti sebagai perubahan paradigma dalam sistem pemerintahan untuk menjamin terselenggaranya tugas-tugas umum pemerintahan dan pembangunan secara berdaya guna dan berhasil guna dan dalam rangka upaya mewujudkan masyarakat yang adil dan makmur baik material maupun spiritual. ${ }^{6}$

Berdasarkan hal di atas, maka penulis memiliki ketertarikan terhadap reformasi birokrasi publik di Indonesia. Alasan yang melatarbelakangi ketertarikan tersebut adalah:

1. Salah satu tuntutan masyarakat terhadap reformasi adalah reformasi birokrasi dalam pelayanan publik. Hal ini mengindikasikan bahwa pelayanan publik pada masa orde baru banyak menerapkan praktik-praktik buruk, sehingga menimbulkan pantangan dan tantangan terhadap proses pelayanan publik dalam era reformasi. ${ }^{7}$

5 Ibid, hlm.2

6 Warsito Utomo, 2006, Administrasi Publik Baru Indonesia; Perubahan Paradigma dari Administrasi Negara ke Administrasi Publik, Yogayakarta : Pustaka Pelajar, hlm. 3

7 Permasalahan yang terjadi terhadap birokratisasi sebelum reformasi di Indonesia meliputi :

a. Kelembagaan birokrasi pemerintah yang besar dan tidak didukung dengan sumber daya aparatur yang profesional;

b. Mekanisme kerja yang sentralistik masih mewarnai kinerja birokrasi pemerintah;

c. Kontrol terhadap birokrasi pemerintah masih dilakukan oleh pemerintah, untuk pemerintah, dan dari pemerintah;

d. Patron-klien (KKN) dalam birokrasi pemerintah merupakan halangan terhadap upaya mewujudkan merirokrasi dan birokrasi;

e. Tidak jelas dan cenderung tidak ada "sense of accountability" baik secara kelembagaan maupun secara individu;

f. Jabatan birokrasi yang hanya menampung jabatan struktural dan pengisiannya sering kali tidak berdasarkan kompetensi yang dibutuhkan; 
2. Baik buruknya suatu pelayanan publik negara sangat dipengaruhi oleh kualitas pelayanannya. Hal ini berarti bahwa sektor pelayanan publik perlu dijadikan fokus kajian dalam globalisasi. Alasan yang mendasarinya adalah fakta keber-hasilan pembangunan terletak pada usaha sistematis dan sungguh-sungguh untuk memperbaiki sistem pelayanan publik, dimana birokrastisasi merupakan faktor dinamis yang memegang peranan penting dalam semua aspek pelayanan publik dan penyelenggaraan pemerintahan. ${ }^{8}$

Berdasarkan hal di atas, maka tulisan ini berangkat dari pemikiran bahwa perubahan paradigma administratif akan berkaitan dengan aspek norma hukum dalam birokrasi publik pemerintahan. Hal ini dilandasi Pertama, kekuasaan dalam menjalankan fungsi pelayanan publik dalam konteks administrasi negara diletak-kan pada kekuasaan (eksekutif) sebagai pelaksana peran. Kedua, kekuasaan dalam penyelenggaraan pemerintahan bersumber dari wewenang formil (formil authority) yang diberikan kepada seseorang atau suatu pihak dalam bidang tertentu. Ketiga, kewenangan yang diberikan tersebut didasarkan pada hukum yang menjadi landasan dalam melaksanakan fungsi administrasi melalui pelimpahan kekuasaan yang diberikan oleh negara. Setidak-tidaknya terdapat dua konsekuensi logis terhadap penggunaan pendekatan normatif. Pertama, pendekatan ini akan berkaitan dengan materi muatan dan fungsi yang ada dalam pengelolaan pemerintahan yang dipahami sebagai runtutan aktivitas yang dinormakan. Kedua, Pendekatan normatif memberikan teknik tertentu pada fungsi-fungsi tertentu yang dijalani dan diaplikasikan pada suatu organisasi, namun didalamnya ter-kandung

g. Penataan sumber daya aparatur tidak disesuaikan dengan kebutuhan dan penataan kelembagaan birokrasi. Lihat Miftah Thoha, 2005, Manajemen Kepegawaian Sipil di Indonesia, Jakarta: Kencana, hal. 3-4

8 Berdasarkan data dari Political and Economic Risk Consultancy dalam Kompas, 22 Juni 2001, Indonesia berada pada kelompok negara-negara yang memiliki indeks competitiveness paling rendah diantara 100 negara paling komptetitif di dunia. Dalam hal ini, terdapat praktik baik dari negara Korea Selatan dan Jepang yang telah melakukan upaya reformasi kepegawaian dan memperbaiki peringkat kualitas birokrasi. Lihat Agus Dwiyanto, dkk, 2006, Reformasi Birokrasi Publik di Indonesia, Yogyakarta:Gadjah mada University Press, hlm. 55 akan nilai-nilai yang bersifat ideal. Keanekaragaman nilai inilah yang sepatutnya dipahami bahwa suatu organisasi tidak beroperasi dalam ruang hampa.

\section{B. Perumusan Masalah}

Filosofi dari perdagangan bebas (free trade) dalam konteks globalisasi adalah no barrier. Hal inilah yang manjadi dasar berkembangnya aspek norma hukum yang fleksibel guna menjawab tantangan globalisasi. Perkembangan tersebut kemudian membawa pada perubahan paradigma dalam pemerintahan yang dapat menunjang aktivitas perdagangan bebas yang berdampak pada keberlangsungan ekonomi suatu negara. Inilah yang menjadi dasar munculnya pembahasan tentang reformasi birokrasi publik. Berdasarkan hal tersebut, maka dapat dirumuskan masalah berupa "Bagaimanakah Perwujudan Good Governance melalui Format Reformasi Birokrasi Publik dalam Perspektif Hukum Administrasi Negara?

\section{Pembahasan}

Konsep global administrative governance melalui penerapan good governance merupakan isu yang digulirkan oleh UNDP (United Nation Develop-ment Program) dan World Bank sejak tahun 1997 sebagai syarat dalam penyaluran dana guna menyelesaikan permasalahan krisis moneter di Indonesia. Hal ini dimaksudkan untuk mempermudah jalur birokrasi publik dalam pemerintahan dan secara tidak langsung sebaga upaya mempermudah akses masuknya perdagangan bebas melalui birokratisasi yang sederhana.

Good governance yang dimaksud merupakan proses penyelenggaraan kekuasaan negara dalam melaksanakan penyediaan public goods and service yang disebut governance (pemerintahan, kepemerintahan), sedangkan praktik terbaiknya disebut "good governance" (tata pemerintahan yang baik). World Bank mendefi-nisikan governance sebagai "the way state power is used in managing economic and social resources for development and society" Sementara UNDP mendefinisikannya 
sebagai "the exercise of political, economic and administrative authority to manage a nation's affair at all levels". Berdasarkan definisi terakhir, maka governance mempunyai tiga kaki (three legs), yaitu :

1. Economic governance meliputi proses pembuatan keputusan (decisions making processses) yang memfasilitasi terhadap equity, poverty dan quality to live;

2. Political governance adalah proses keputuan untuk formulasi kebijakan;

3. Administrative governance adalah implementasi proses kebijakan. ${ }^{9}$

Ketiga elemen di atas merupakan suatu proses kegiatan yang saling me-lengkapi. Namun menurut konsep Weber, konsep birokrasi hanyalah merupakan sebuah mesin yang disiapkan untuk men-jalankan dan mewujudkan tujuantujuan negara yang masuk dalam ranah administrative governance. Dengan demikian, setiap pekerja atau pejabat dalam pelayanan publik pemerintah merupakan pemicu dan penggerak dari sebuah mesin yang tidak mempunyai kepentingan pribadi (each individual civil servant is a cog in the machine with no personalities interest). Dalam kaitan ini, maka setiap pejabat pemerintah tidak mempunyai tanggung jawab publik, kecuali pada bidang tugas dan tanggung jawab yang dibebankan kepadanya. Pemikiran seperti ini menjadikan pelayanan publik pemerintah bertindak sebagai kekuatan yang netral dari pengaruh kepentingan kelas atau kelompok tertentu. ${ }^{10}$

Didasarkan pada pembagian di atas, maka birokrasi publik sebagai bagian dari Hukum Administrasi Negara merupakan aspek penting dalam pelaksanaan fungsi pelayanan publik guna menciptakan good governance. Sehubungan dengan agenda reformasi nasional, Bintoro Tjokroamidjojo mengutarakan bahwa keberhasilan pembangunan aparatur negara dalam rangka mewujudkan tata pemerintahan yang baik dalam era reformasi dewasa ini, paling tidak dapat dilihat dari seberapa jauh keberhasilan pen-

\footnotetext{
9 Soedarmayanti, 2003, Good Governance (Kepemerintahan Yang Baik) Dalam Rangka Otonomi Daerah, Bandung:Mandar Maju, hlm. 4

10 Miftah Thoha, 2008, Birokrasi Pemerintah Indonesia di Era Reformasi, Yogyakarta: Prenada Media Group, hlm. 21
}

capaian tujuan reformasi sebagaimana tercantum dalam Bab III TAP MPR No.VIII/MPR/ 1998 yang mencakup :

1. Mengatasi krisis ekonomi dalam waktu sesingkat-singkatnya terutama untuk menghasilkan stabilitas moneter yang tanggap terhadap pengaruh global dan pemulihan aktivitas usaha nasional;

2. mewujudkan kedaulatan rakyat dalam seluruh sendi kehidupan masyarakat, berbangsa dan bernegara melalui perluasan dan peningkatan partisipasi politik rakyat secara tertib untuk menciptakan stabilitas nasional;

3. menegakan hukum berdasarkan nilai-nilai kebenaran dan berkeadilan, hak azasi manusia menuju terciptanya ketertiban umum dan perbaikan sikap mental;

4. meletakan dasar-dasar kerangka dan agenda reformasi pembangunan, agama dan sosial budaya dalam usaha mewujudkan masyarakat madani. ${ }^{11}$

Sedangkan, agenda reformasi pemerintahan dalam rangka mewujudkan tata pemerintahan yang baik perlu diarahkan kepada:

1. Perubahan sistem politik ke arah sistem politik yang demokratis, partisipatif dan egalitarian;

2. Reformasi dalam sistem pelayanan publik militer (TNI) dimana kekuatan militer ini harus menjadi kekuatan yang profesional dan independen, bukan menjadi alat politik partai atau kekuasaan pemerintah yang mendudukannya sebagai keuatan pertahanan negara;

3. Reformasi dalam bidang administrasi publik perlu diarahkan pada peningkatan. Profesionalisme pelayanan publik pemerintah dalam rangka meningkatkan pengabdian umum, pengayoman, dan pelayanan publik;

4. Reformasi pemerintahan yang juga penting adalah perubahan dari pola sentralisasi ke desentralisasi, bukan dalam rangka separatisme atau federalisme;

11 Bintoro Tjokroamidjojo, 2000, Good Governance, Paradigma Baru Manajemen Pembangunan, Jakarta: UI Press, hlm. 88 
5. Agenda aksi reformasi lainnya yang juga strategis adalah menciptakan pemerintahan yang bersih (clean government) yang terdiri dari tiga pokok agenda, yaitu :

a. Mewujudkan pemerintahan yang bersih dari praktik-praktik Korupsi, Kolusi, Kroniisme dan Nepotisme (KKKN);

b. Disiplin penerimaan dan penggunaan uang/ dana rakyat, agar tidak lagi mengutamakan pola deficit funding dan mengapuskan adanya dana publik non-budgeter;

c. Penguatan sistem pengawasan dan akuntabilitas publik aparatur negara. ${ }^{12}$

Berdasarkan hal di atas, maka prinsip dasar yang melandasi perbedaan antara konsepsi tata pemerintahan (governance) dengan pola pemerintahan yang tradisonal adalah terletak pada adanya tuntutan yang demikian kuat agar peranan pemerintah dikurangi dan peranan masyarakat ditingkatkan dan semakin terbuka aksesnya. Perspektif good governance tersebut meng-implikasikan adanya pengurangan peran dari pemerintah, namun hal ini tidak serta merta meninggalkan peran pemerintah begitu saja. Terdapat 6 (enam) prinsip yang menyatakan terdapatnya peran pemerintah yang signifikan dalam proses governing.

1. Dalam kolaborasi yang dibangun, negara (pemerintah) tetap bermain sebagai figur kunci namun tidak mendominasi, dan memiliki kapasitas mengkoordinasi (bukan memobilitasi) aktor-aktor institusi semi dan non pemrintah untuk mencapai tujuan-tujuan publik;

2. Kekuasaan yang dimiliki negara harus di transformasikan, dari yang semula dipahami sebagai "kekuasaan atas" menjadi "kekuasaan untuk" menyelenggarakan kepentingan, memenuhi kebutuhan dan menyelesaikan masalah publik;

3. Negara, NGO, swasta dan masyarakat lokal merupakan aktor-aktor yang memiliki posisi dan peran yang saling menyeimbangkan (untuk tidak menyebut setara);

4. Negara harus mendesain ulang struktur dan kultur oraganisasinya agar siap dan mampu menjadi katalisator bagi institusi lainnya untuk menjalin sebuah kemitraan yang kokoh, otonom dan dinamis;

5. Negara harus melibatkan semua pilar masyarakat dalam proses kebijakan mulai dari formulasi, implementasi dan evaluasi kebijakan serta penyelenggaraan layanan publik;

6. negara harus mampu meningkatkan kualitas responsivitas, adaptasi dan akuntabilitas publik dalam penyelenggaraan kepentingan, pemenuhan kebutuhan, dan penyelesaian masalah publik. ${ }^{13}$

Berikutnya, UNDP (United nation Development Program), mengemukakan bahwa karakteristik tata prinsip yang harus dianut dan dikembangkan dalam praktik good governance meliputi :

1. Partisipasi (participation)

Setiap orang atau warga masyarakat memiliki hak suara dalam proses pengambilan keputusan, baik secara langsung, mau pun melalui lembaga perwakilan sesuai dengan kepentingan dan aspirasinya masingmasing.

2. Aturan Hukum (Rule of Law)

Kerangka aturan hukum dan perundangundangan harus berkeadilan, ditegakan dan dipatuhi secara utuh, terutama aturan hukum tentang Hak Asazi Manusia.

3. Transparansi (Tranparency)

Transparansi harus dibangun dalam rangka kebebasan aliran informasi.

4. Daya Tanggap (Responsivenes)

Setiap institusi dan prosesnya harus di arahkan pada upaya untuk melayani berbagai pihak yang berkepentingan (stakeholder)

5. Berorientasi konsensus (Concencuss Orientation)

Pemerintahan yang baik akan bertindak sebagai penengah bagi berbagai kepentingan yang berbeda untuk mencapai konsensus atau kesempatan yang terbaik bagi kepentingan masing-masing pihak dan jika dimungkinkan juga dapat diberlakukan

${ }^{13}$ Agus Dwiyanto, 2008, Op.cit, hlm.79 
terhadap berbagai kebijakan dan prosedur yang akan ditetapkan pemerintah.

6. Berkeadilan (Equity)

Pemerintahan yang baik akan memberikan kesempatan yang terbaik terhadap subyek hukum dalam upaya mereka untuk meningkatkan dan memelihara kualitas hidupnya.

7. Efektivitas dan Efisiensi (Effectiveness adn Efficiency)

Setiap proses kegiatan dan kelembagaan di arahkan untuk menghasilkan sesuatu yang benar-benar sesuai dengan kebutuhan melalui pemanfaatan yang sebaik-baiknya berbagai sumber-sumber yang tersedia.

8. Akuntabilitas (Accountability)

Para pengembil keputusan dalam organisasi sektor publik, swasta dan masyarakat mempunyai pertanggungjawaban (akuntabilitas) kepada publik (masyarakat umum) sebagaimana halnya kepada para pemilik (stakeholder)

9. Visi strategis (Strategic Vision)

Para pemimpin dan masyarakat memeiliki perspektif yang luas dan jangka panjang tentang penyelenggaraan pemerintahan yang baik dan pembangunan manusia, bersamaan dengan dirasakannya kebutuhan untuk pembangunan tersebut ${ }^{14}$

Selain dari yang diatas, ada pula yang menyebutkan 10 (sepuluh) prinsip meliputi :

1. Partisipasi warga memiliki hak (dan mempergunakannya) untuk menyampaikan pendapat, bersuara dalam proses perumusan kebijakan publik, baik secara langsung maupun tidak langsung;

2. Penegakan hukum, hukum diberlakukan bagi siapapun tanpa pengecualian, hak asasi manusia dilindungi, sambil tetap memperhatikan nilai-nilai yang hidup dalam masyarakat;

3. Transparansi, penyediaan informasi tentang pemerintah(an) bagi publik dan di jaminnya kemudahan di dalam memper-oleh informasi yang akurat dan memadai;

\footnotetext{
${ }^{14}$ Soedarmayanti, Op.cit, hlm.5-6
}

4. Kesetaraan, adanya peluang yang sama bagi setiap anggota masyarakat untuk beraktivitas/berusaha;

5. Daya tanggap pekanya para pengelola instansi publik terhadap aspirasi masyarakat;

6. Wawasan ke depan, pengelolaan masyarakat hendaknya dimulai dengan visi, misi dan strategi yang jelas;

7. Akuntabilitas, pertanggungjawaban para penentu kebijakan kepada para warga;

8. Pengawasan publik, terlibatnya warga dalam mengontrol kegiatan pemerintah termasuk parlemen;

9. Efektivitas dan efisiensi, terselenggaranya kegiatan instansi publik dengan menggunakan sumber daya yang tersedia secar optimal dan bertanggung jawab. Indikatornya antara lain: pelayanan mudah,cepat, tepat dan murah;

10. Profesionalisme, tingginya kemampuan dan moral para pegawai pemerintah. ${ }^{15}$

Berdasarkan prinsip-prinsip yang di kemukakan di atas, maka good governance memberi-kan pengaruh terhadap reformasi birokrasi publik dalam Hukum Administrasi Negara. Dalam sistem penyelenggaraan pemerintahan, hal tersebut kemudian berdampak pada sistem kelembagaan, ketatalaksanaan, dan sumber daya manusia aparatur yang ada di Indonesia.

1. Pengaruh di bidang kelembagaan adalah me-nata ulang struktur organisasi dengan prinsip rasional dan realistik (sesuai kebutuhan) dan perangkat kelembagaan yang lebih efektif serta efisien yang berorientasi pada peningkatan pelayanan masyarakat. Hal ini menuntut pula pada penyediaan sarana dan prasarana pemerintahan yang dapat mendukung terwujudnya pelayanan prima bagi masyarakat. Contoh peraturan yang selaras dengan nuansa kelembagaan Undang-Undang No.32 tahun 2004 tentang Pemerintahan Daerah.

2. Di bidang ketatalaksanaan, pengaruhnya ada-lah penyempurnaan kualitas dan

${ }^{15}$ Lihat http://www.goodgovernance.or.id/sitemap. asp (on line) diakses tanggal 10 Mei 2009 
transparansi pelayanan masyarakat terhadap perubahan-perubahan dan tuntutan-tuntutan masyarakat, oleh karena itu diperlukan penyempurnaan sistem ketatalaksanaan dalam penyeleng-garaan tugas-tugas umum pemerintahan dan pembangunan. Contoh peraturan yang selaras dengan nuansa ketatalaksanaan adalah Undang-undang tentang Pelayanan Publik

3. Bidang sumber daya manusia aparatur sebagai pilar utama penyelenggaraan pemerintahan berpengaruh pada pengembangan sistem perencanaan Sumber Daya Manusia aparatur pemerintah sesuai hasil penataan struktur dan perangkat kelembagaan daerah. Konsekuensinya adalah pembentukan disiplin, etika dan moral di tingkat pelaksana yaitu Pegawai Negeri Sipil yang bertujuan untuk meningkatkan produktivitas kerja dan tuntutan terhadap perwujudan aparatur pemerintah yang bebas Korupsi Kolusi. Nepotisme (KKN) dan lebih profesional. Contoh peraturan yang selaras dengan nuansa sumber daya manusia aparatur adalah Undang-Undang No.43 tahun 1999 tentang Pokok-Pokok Kepegawaian.

\section{Penutup}

Global administrative governance memberikan pengaruh yang signifikan dalam reformasi birokrasi publik, terutama dalam merubah paradigma yang bersifat konvensional dalam penataan sistem kelembagaan, ketatalaksanaan, dan sumber daya manusia aparatur di Indonesia. Dalam hal ini, aspek Hukum Administrasi Negara merupakan bagian dari ranah hukum yang secara langsung terpengaruh dalam upaya mewujudkan reformasi birokrasi publik. Perubahan yang bersifat global ini didasarkan pada standar nilai yang bersifat universal yang dapat meningkatkan peran serta pemerintah, masyarakat dan swasta dalam pelaksanaan fungsi pemerintahan. Konsekuensi dari peran serta tersebut adalah terdapatnya banyak pelaku, jaringan dan institusi di luar pemerintah yang masuk dan mempengaruhi pengelolaan masalah dan kebutuhan publik yang riil.

\section{Daftar Pustaka}

\section{Buku Literature}

Bappenas. 2002. Tingkat Pemahaman Aparatur Pemerintah Terhadap Prinsip-- Tata Pemerintahan Yang Baik. Jakarta: Badan Perencanaan Pembangunan Nasional;

Dwiyanto, Agus. 2006. Reformasi Pelayanan publik Publik di Indonesia. Yogyakarta: Gadjah Mada University Press; 2008, Mewujudkan Good Governance Melalui Pelayanan Publik. Yogyakarta: Gadjah Mada University Press;

Siagian, Sondang P. 1996. Filsafat Administrasi. Jakarta: PT. Gunung Agung;

Soedarmayanti. 2003. Good Governance (Kepemerintahan Yang Baik) Dalam Rangka Otonomi Daerah. Bandung: Mandar Maju;

Thoha, Miftah. 2005. Manajemen Kepegawaian Sipil di Indonesia, Jakarta: Kencana;

2008. Pelayanan publik Pemerintah Indonesia di Era Reformasi. Yogyakarta: Prenada Media Group;

Tjokroamidjojo, Bintoro. 2000. Good Governance, Paradigma Baru Manajemen Pem-bangunan. Jakarta: UI Press;

Utomo, Warsito. 2006. Administrasi Publik Baru Indonesia; Perubahan Paradigma dari Ad-ministrasi Negara ke Administrasi Publik. Yogayakarta: Pustaka Pelajar.

\section{Artikel di Internet}

http://www.goodgovernance.or.id/sitemap.a sp (on line) diakses tanggal $10 \mathrm{Mei}$ 2009. 
